腹壁瘢痕ヘルニアが併存した両側 Spigel ヘルニアの 1 例

\author{
石巻市立病院外科 \\ 木 村良直* 伊 勢 秀 雄
}

原発性腹壁へルニアの中でも極めて稀な Spigel ヘルニアの両側例を経験したので報 告すう。症例は70歳の女性で子宮癌に対する子宮全摘と右腹壁へルニアに対する修復術 の既往がある. 腹痛を主訴に近医受診, 腹部 CT で臍の両側に腹壁内に突出する2つの ヘルニアを認め, 嵌頓疑いで当院紹介となった. 腹部 CT 所見から両側の Spigel ヘルニ アと診断したが，著しい肥満のために視触診ではへルニアの膨隆は不明瞭であった。ま た下腹部には整状に突出している腹壁般痕へルニアが併存していた。手術所見では左右 の Spigel ヘルニアはそれぞれ10 $\times 5 \mathrm{~cm}$ と大きなへルニア門を有し, 右は再発性の偽へ ルニアであった. 3 カ所のへルニアに対し, polypropylene mesh を用いた修復術を施行

した。術後に皮庯瘦形成をきたしたが, 術後 3 年経過し再発は認めていない.

索引用語 : Spigel ヘルニア, 両側 Spigel ヘルニア

\section{緒言}

Spigel ヘルニアは腹直筋外緑の構造上脆弱な Spigel 腱膜に発生する稀な腹壁ハルニアである.今回 われわれは, Spigel ヘルニアの両側例を経験したので 報告する.

$$
\text { 症例 }
$$

症例：70歳, 女性.

主訴: 吐気, 腹痛.

家族歴：特記事項なし。

既往歴：46歳時に子宮癌で子宮全摘術および術後体 外照射. 68 歳時に右腹壁ヘルニア嵌頓でヘルニア修復 術.

現病歴：以前より時々，腹部の重苦感があったか， 平成11年10月 3 日, 腹痛出現し, 翌日に近医受診. 腹 部 CT で臍の両側に対称的に存在する2つの大きな腹 壁ヘルニアを指摘され，嵌頓疑いで当院紹介，入院と なった。

入院時現症：身長 $151 \mathrm{~cm}$, 体重 $63 \mathrm{~kg}$ と肥満を認め た. 眼瞼結膜に負血, 眼球結膜に黄疸を認めなかった。 腹部には既往の 2 つの手術創が認められ，下腹部正中

20 (1) 年1月27日受付 2004 年 2 月2 日採用

*現：中嶋病院外科

〈所属施設住所〉

=986-0835 石巻市南浜町 $1-7-20$
に堡状で硬い腹壁痽痕ヘルニアがあり, 周囲の皮膚に は照射療法による著しい線維化が認められた。肥満が 強く, 視触骖上, ヘルニアの膨隆は不明瞭で圧痛も認 めなかった（図 1 )。

入院時検査所見: WHC $17,2(00 / \mu l, C R P \& .0 \mathrm{mg} / \mathrm{dl}$ と炎症所見を認めたか，その他には異常値を認めなか った。

腹部単純 $\mathrm{X}$ 線検査：腸閉塞を示唆するような異常 所見を認めなかった。

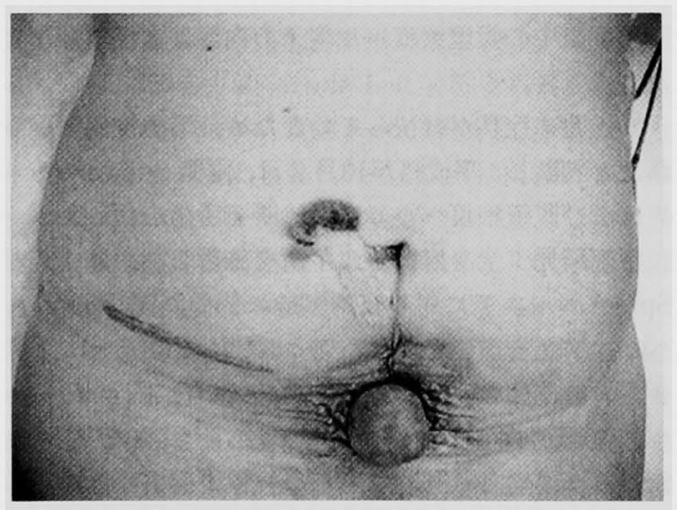

図 1 下腹部所見：正中創の下端に若状の硬い腹壁疫痕 ヘルニアと右下腹部に腹壁へルニアの手術痽痕を認め る、腹部に腫瘤は触知しない。 


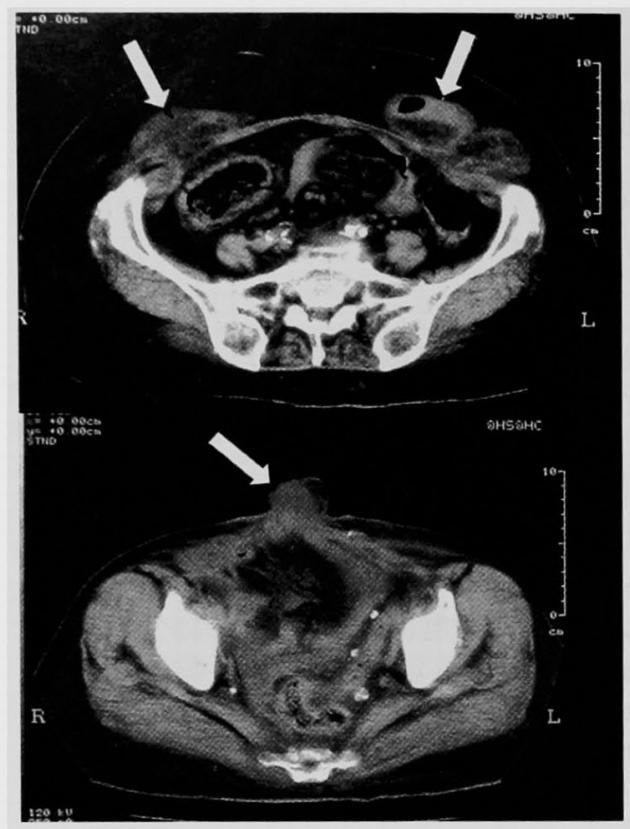

図 2 腹部 CT 所見：a )腸骨稜の高さ。両側性に腹 壁内に突出する大きないルニア (矢印) を認めた。 b) 下腹部正中に襄状の腹壁へルニア (矢印) を認 めた。

$$
\frac{a}{b}
$$

腹部 CT 所見 (図 2 )：腸骨稜の高さで, 左右対称性 に腹壁内に突出する大きな2つのへルニアを認め, 左 側ではハルニア内に腸管内ガス像を認めた。

腹部 IIRI 所見 (図 3)：両側の腹直筋外縁より腹壁 内に突出するへルニアを認め, ヘルニア門は大きく, 内容が腸管および大網であることが描出された。また， 下腹部正中の腹壁瘢痕へルニアの内容は大網と診断し た。

搬送時に症状が軽快していたため，緊急性は解除さ れたと判断し, 平成11年10月 7 日, 両側 Spigel ヘルニ アおよび腹壁痺痕へルニアの診断で手術を行った。

手術所見：全身麻酔下に手術を施行した。まず，左 Spigel ヘルニアに対し皮雷割線に沿った皮切を行い, ヘルニア門を露出した.ヘルニア門は $10 \times 5 \mathrm{~cm}$ と大 きく, 内側は腹直筋外縁に一致していた(図 4 a). ルニア䧶を切除しへルニア門を閉鎖する前に右 Spigel ヘルニアの処理に移った. 手術緳痕を切除する ように皮切し，ヘルニアの膨隆部分を露出し，左の Spigel ヘルニアより腹腔内に手をいれて検索すると， 右 Spigel ヘルニアの腹膜縫合部は長径方向で大きく

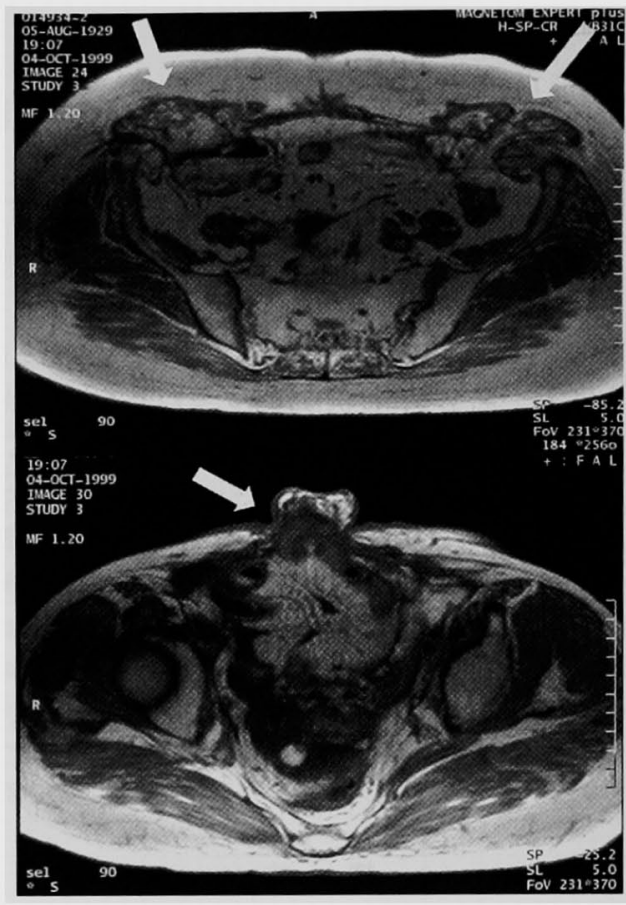

図 3 腹部 MRI 所見：a）両側腹直筋の外縁より腹 壁内へ突出する両側性のへルニア (矢印)を認めた。 b) 下腹部の腹壁㾍痕ハルニア (矢印) 内には腸管 は認めなかった。

$\frac{\mathrm{a}}{\mathrm{b}}$

離開しており，ハルニア蘘を有しない偽ヘルニアで右 Spigel ヘルニアの術後再発と診断した(図 4 b). ヘル ニア門の位置，大きさは左右ともほほ同じで，右は筋 膜層が保たれているため嵌頓の危険はないと考えへル ニア䧶を開放せず, polypropylene mesh を外腹斜筋腱 膜前面で縫合固定し，膨隆部を被覆，補強するに留め た。左はヘルニア門を縫合閉鎖し，筋膜上に polypropylene mesh を縫合固定し補強した（図 5 a). 続

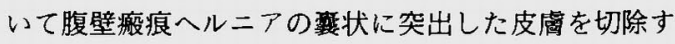
ると, 炎症性の脂肪壊死を伴った大網をへルニア直下 に認め，嵌頓していた部分と考えられた．同部は照射 療法による線維化が著しく一期的閉鎖が困䨅で, poly. propylene mesh によりへルニア門を覆うように全周 縫合固定し, 皮虔縫合では左 Spigel ヘルニアと創を連 続させ,トリミングを行い閉創した（図５ｂ）.

術後経過：抜系直後，洀痕へルニア部の皮成縫合部 にピンホールの皮虔瘦形成を認めたが, 術後 3 年経過 し再発は認めていない. 


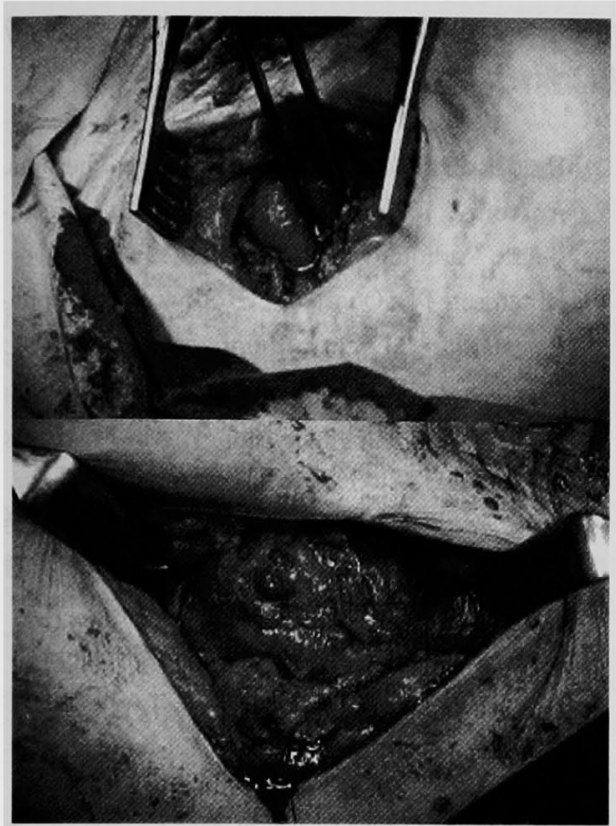

図 4 手術所見

a 左 Spigel ヘルニア：ヘルニア襄を切除し内 容の小腸を確認した。

b 右 Spigel ヘルニア : 膨隆の範囲を確認する に留め，開放しなかった。

\section{考 察}

Spigel ヘルニアは半月状線ヘルニアとも称され, 腹 横筋が筋成分から腱膜に移行する部分である半月状線 と腹直筋外縁との間の Spigel 腱膜に発生する稀な原 発性腹壁へルニアで，その発生頻度は全腹壁へルニア の $2 \%$ 以下言われている”. Klinkosch"2が1764年に 第 1 例を報告して以来, 病名の普及とともに症例報告 が増加しているが両側例は極めて珍しい. 欧米では Spangen ${ }^{3)}$ が Spigel ヘルニア876例中29例 (3.3\%) の両 側例を報告しているが，本邦では今村ら゙の同側多発 例を除けば，自験例が 2 例目である5).

原田ら ${ }^{5)}$ は本邦における Spigel ヘルニア56例につい て検討し, 平均年齢は53.5歳で, 生後 6 力月から83歳 までに及び，男女比は0.64：1でやや女性に多く，左 右差は認めなかったとし, Spangen ${ }^{3)}$ 報告にほほ一 致している。

本疾患の主な自覚症状は腫瘤と疼痛であるが，小さ なへルニアのため自覚症状にそしい例や口，分類不明 の腹壁ヘルニアとして処理されている例もあり，実際
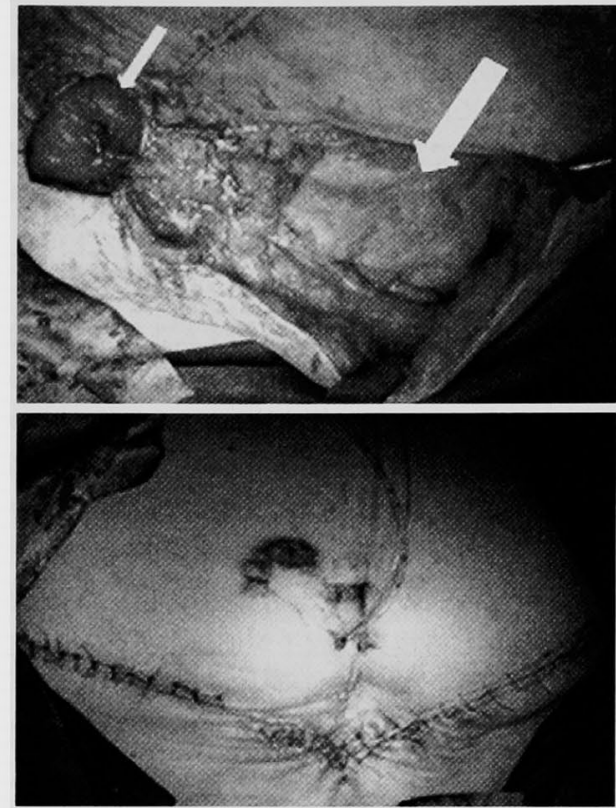

図 5 手術所見：a）左 Spigel ヘルニアを縫合閉鎖 後, meshにより被覆, 固定し(太矢印), 腹壁㓔痕 ヘルニア (細矢印) へ創を連続させた， b ) 手術終 了時. 左 Spigel ヘルニアと腹壁瘏痕へルニアは連 続した一つの創として閉創した。 $\frac{\mathrm{a}}{\mathrm{b}}$

にはさらに多いものと思われる．自験例でも腹部の重 苦感はあったがヘルニアの膨隆は自覚されておらず, 既往である右側腹部の手術時には, 単に右腹壁へルニ アの嵌頓と説明されていた。

本疾患が念頭に固かれていれば，ヘルニアの発生場 所と画像診断により術前診断は可能である。発生場所 としては, Spigelian hernia belt と称される左右の上 前腸骨棘を結ぶ線から頭側 $6 \mathrm{~cm}$ の範囲に発生するも のが $90 \%$ 占めると言われ31，自験例は両側ともこの Spigelian hernia belt からの発生であった. しかし季

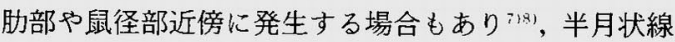
との位置関係で診断することが原則である、へルニア 門の大きさについては，欧米の報告例はほとんどが 2 $\mathrm{cm}$ 以下と小さいが31，本邦では $5 \mathrm{~cm}$ を超える大きな ものが約 $30 \%$ 占めていた ${ }^{4153}$. また，嵌頓や腸閉塞と いった合併症により発見される症例が約 $20 \%$ 認められ ているが45)，自験例では両側の Spigel ヘルニアでの 嵌頓ではなく，腹壁㾘痕へルニアでの大網の嵌頓があ ったものと考えられた。 
画像診断では腹部し丁の有用性が高いとされる が星10), 自験例の場台, ヘルニア門およびヘルニア内容 の描出に㧍いて，腹部 MRIがより明瞭な画像を示し た．今回は施行できなかった矢状断撮影も行えれば, ヘルニア門の同定や多発例の見逃し防止にも有用で， 緊急性がない場合には行ってみる価值があると考えら 机た。

本疾患の発生が先天性であるか後天性なのか㹥統一

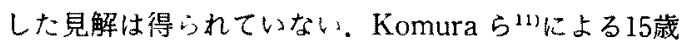
以下の Spigel ヘルニア23例の検討では, 生後 6 日の 1 例を含む17例が先天性と診断され、うち4例が両側例 であり，後天性とされた 6 例は外傷や腹部手術に続発 していた，一方，本疾患の発生は60〜80歳にピークを 認めて坊り", 肥満, 妊娠出産, 腹水貯留, 腹部外傷, 開腹手術後などの後天的因子が加わって Spigel 腱膜 の菲薄化をきたし発症する機序が考えら机ている．自 験例で下腹部の手術後,肥満と後天的因子が存在し， さらに体外照射により下腹部前腹壁が硬化し前方への 進展性が失われ，外側方向への腹圧が增強し Spigel 腱 膜の菲薄化に拍車をかけたものと推察された。

治療法法手術が唯一の根治法てある。他のへルニア の手術同様, ヘルニア門の閉鎖が必要となるが, 嵌頓 や絞拒がない限り・ルニア禁の処理は必ずしも必要で はない。，小さなハルニアの場合, 単純閉鎖のみで良好 去治療成績が得られており再発率は $0.7 \%$ 程度とされ る3゙.一方，大きなハニア門を有する症例ては腱膜の 脆弱部位を polypropylene mesh で補強する方法の有 用性が報告されている(5)812). 自験例においても poly. propylene mesh 用いて修復, 補強を行ったか, 右 Spigel ヘルニアは単純閉鎖術後の再発と考方られ，人 ルニア門の大きな症例に対する単純閉鎖は十分な術式 とは言之ない可能性を示唆しており，再発防止策とし ての mesh の使用は有用であると考えられた。

$$
\text { 結語 }
$$

腹壁瘦痕ヘルニアが併存した Spigel ヘルニアの極
めて珍しい両側例を経験したのて，若干の文献的考察 を加え報告した。

\section{文献}

1) Holder LE, Schneider HJ : Spigelian hernias. Anatomy and roentgenographic manifestations. Radiology 112: 309-313, 1974

2) Klinkosch JT : Quoted by Holloway JK : Spontaneous lateral ventral hernia. Ann Surg 75: $677-685,1922$

3) Spangen L: Spigelian hernia. World J Surg 13 : 573-580, 1989

4) 个村 秀, 安蘓正和, 三井信介他：イレウスを発 症した Spigel ヘルニア多発の 1 例. 日殑外会誌 $62: 1315-13 \%(1) 2001$

5）原田直樹, 西尾吉正, 豊田紘生：岡側 Spigel へル 二アの1例．日臨外会誌 $64: 2883-2887,2003$

6) 中川国利, 佐藤 俊, 安田 保他: Spigel ヘルニ アの1例。消外 $17: 1773-1775,1994$

7) 山本協二, 梅澤昭子, 徳村弘㬰地：右季肋部に発 生した大きな Spigel ヘルニアの1例. 日臨外会誌 $59: 1423-142 i, 1998$

8) 内藤浩之, 吞村孝之, 高橋忠照他：外鼠径へル二 アを合併した Spigel ヘルニアの1例. 日臨外会誌 $62: 2543-2546,2001$

9）塩田喜代美, 植木孝宜, 青井重善他：CTにて蒲前 診断した半月状線ヘルニアの1例。日臨外会誌 $63: 1308-1311,2002$

10）窪田公一, 高橋 弘, 小川健治他：明瞕な $\mathrm{CT}$ 像 を呈したSpigelへルニアの1例.日臨外会誌 $63: 491-494,2002$

11) Komura J. Yano H. Uchida M. et al: Pediastric Spigelian Hernia: Reports of Three Cases. Surg Today, Jpn J Surg 24: 1081-1684, 1994

12）哄 博臣, 染谷哲史, 戸塚守夫他: Spigel ヘルニ Pの 1 例. 日臨外会誌 $61 ： 513-517,2000$ 


\title{
A CASE OF BILATERAL SPIGELIAN HERNIAS WITH AN INCISIONAL HERNIA
}

\author{
Yoshinao KIMURA and Hideo ISE
}

Department of Surgery, Ishinomaki Municipal Hospital

We present a case of bilateral Spigelian hernias, extremely rare among primary abdominal wall hernia. A 70-year-old woman who had undergone total hysterectomy for uterine cancer and repair of a right abdominal wall hernia and admitted for abdominal pain was found to have 2 large abdominal wall hernias on both sides of the navel on abdominal CT and was subsequently refered to our hospital with a suspicion of incarceration of the hernias.

We diagnosed these as bilateral Spigelian hernias by CT but the hernias were difficult to recognize by inspection or palpation owing to the woman's obesity. She also had an incisional hernia cystically protruding into the lower abdomen. At surgery, each Spigelian hernia had large hernial orifices of $10 x$ $\bar{j} \mathrm{~cm}$ in diameter and the one at right was diagnosed as recurrent pseudohernia. These three hernias were repaired using polypropylene mesh sheets.

The patient suffered from a cutaneous fistula just after surgery, but has been in good health without signs of recurrence in the 3 years since surgery. 